\title{
Investigation of glycated protein assay for assessing heat treatment effect in food samples and protein-sugar models
}

\author{
Ilhame Bourais $^{\mathrm{a}}$, Aziz Amine ${ }^{\mathrm{a}, *}$, Danilla Moscone ${ }^{\mathrm{b}}$, Giuseppe Palleschi ${ }^{\mathrm{b}}$ \\ ${ }^{a}$ Faculté des Sciences et Techniques de Mohammedia, Universit HassanII-Mohammedia, G.P.E., B.P. 146, Mohammedia, Morocco \\ b Dipartimento di Scienze e Tecnologie Chimiche, Università di Roma "Tor Vergata", Italy
}

Received 5 August 2004; received in revised form 13 February 2005; accepted 14 February 2005

\begin{abstract}
A commercial kit (Gly-Pro), usually used for clinical diagnosis relative to diabetes, was employed to estimate the effect of heat treatment applied to food and also protein-sugar model systems. The assay employs two enzymatic reagents that react with glycated proteins that result from the Maillard reaction; the hydrogen peroxide produced is then consumed in a colorimetric reaction. Food samples and model systems were heated and incubated at different temperatures and holding times. The enzymatic method was demonstrated to be useful for detecting early products of the Maillard reaction. However, the Gly-Pro kit seems to be specific for glucose binding proteins.
\end{abstract}

(C) 2005 Elsevier Ltd. All rights reserved.

Keywords: Maillard reaction; Glycated protein; Heat treatment; Gly-Pro assay

\section{Introduction}

The Maillard reaction (MR) is a cascade of chemical reactions occurring during the processing and storage of foods containing reducing sugars and proteins. The most common modifications of physicochemical and nutritional properties of food products are, in fact, attributed to these reactions.

Maillard first described this reaction in 1912 (Maillard, 1912). In summary, the scheme is that reducing sugars, such as glucose, condense with compounds possessing $\alpha$ - or $\varepsilon$-free amino groups, such as proteins, to give condensation products. A range of reactions then takes place, which ultimately lead to the formation of brown nitrogenous polymers.

It is useful to consider three stages in the MR: initial, advanced and final stages. Sugar initially reacts revers-

\footnotetext{
* Corresponding author. Tel.: +212 61 454198; fax: +212 23315353 .

E-mail address: a.amine@univh2m.ac.ma (A. Amine).
}

ibly with the free protein amino-groups to produce a Schiff base which undergoes an irreversible Amadori rearrangement, to produce a ketoamine also referred as an Amadori product. The advanced Maillard reaction consists of dehydratation and fission of the Amadori product into colourless reductones as well as furfurals (Hodge, 1953), which condense with themselves or with aldehydes formed by Strecker degradation of amino acids and form brown pigments (Morales \& Van Boekel, 1997).

The final stage of the MR is then the one in which most of the colour is produced. This stage is characterized by the formation of unsaturated, brown nitrogenous polymers and copolymers and although nitrogen-free polymers (Ames, 1992; Hodge, 1953).

Several compounds, which result from MR induced changes in the products, can then be considered as "markers" of food processing and storage variables. These indicators includes the Amadori compound ( $N$-substituted 1-amino-1-deoxy-2-ketose), 
furosine ( $\varepsilon-N-2$ (furoylmethyl)-L-lysine) produced by acid hydrolysis of the Amadori product (Finot, Deutch, \& Bujard, 1981; Hidalgo, Pompei, \& Zambuto, 1998; Hidalgo, Rossi, \& Pompei, 1995; Villamiel, Corzo, Martinez-Castro, \& Olano, 1996), hydroxy methyl furfural (HMF) (Hidalgo \& Pompei, 2000; Morales, Romeo, \& Jiménez-Pérez, 2000; Mortier, Braekman, Cartuyvels, Renterghem, \& De Block, 2000), and lactulose as heat index in milk (Amine, Moscone, Bernardo, Marconi, \& Palleschi, 2000; EU Commission, 1992; IDF, 1998; Marconi et al., 2004; Moscone, Bernardo, Marconi, Amine, \& Palleschi, 1999). In the advanced stage of the MR, the production of pigments is monitored spectrophotometrically (Buera, Chirife, Resnik, \& Wetzler, 1987; Pagliarini, Vernile, \& Pei, 1990; Rampilli \& Andreini, 1992) or via fluorescence (Morales \& Van Boekel, 1997) either in food or in protein-sugar models.

With regard to glycated proteins, most studies have been confined to model systems (Chevalier, Chobert, Mollé, \& Haertlé, 2001a; Chevalier, Chobert, Popineau, Nicolas, \& Haertlé, 2001b; Morgan et al., 1998; Pellegrino, Van Boekel, Gruppen, Resmini, \& Pagani, 1999). They were also determined in pasteurized milk and UHT milk by ELISA methods (Pallini et al., 2001; Pizzano, Nicolai, Siciliano, \& Addeo, 1998).

The purpose of this work is to study the effect of storage and intensity of heat treatment on protein glycation and on the Maillard reaction by use of an enzymatic method based on spectrophotometric measurement. The evolution of glycated protein in food samples and proteinsugar models was evaluated to afford information about processing and storage effects on product quality.

In the present paper, we examined the applicability in food field of the Gly-Pro assay enzymatic kit, which is commonly used for a quantitative determination of glycated serum proteins in diabetic patients (Torrens, Shipley, Holdrige, Lane, \& Kalwass, 1998).

\section{Materials and methods}

\subsection{Reagents}

Enzymatic reagents of the GLY-PRO assay Kit were purchased from Genzyme (UK). The reagent 1 vial, containing lyophilized proteinase $\mathrm{K}$ and peroxidase, was reconstituted with $25.0 \mathrm{ml}$ of purified water, while the reagent 2, which contains ketoamine oxidase, was reconstituted with $5.0 \mathrm{ml}$ of $\mathrm{H}_{2} \mathrm{O}$. The reagents were gently mixed and allowed to stand for $10 \mathrm{~min}$ before use. Once reconstituted, they are stable for up to 70 days at $2-8{ }^{\circ} \mathrm{C}$ or 21 days at $25^{\circ} \mathrm{C}$.

Glucose, lactose, fructose, galactose, sucrose, casein and BSA used for preparing model systems were purchased from Sigma Aldrich.

\subsection{Protein glycation model systems}

Glucose-protein mixtures were prepared in sodium phosphate buffer $0.1 \mathrm{M}$, pH 8.5, containing $3.2 \%$ (W/ $\mathrm{V})$ of casein or BSA and $0.5 \%(\mathrm{~W} / \mathrm{V})$ of sugar. Model system solutions $(10 \mathrm{ml})$ were heated at 37 and $60^{\circ} \mathrm{C}$ for various times in tightly stoppered glass tubes, which were immersed in water bath. After predetermined times, the tubes were withdrawn and cooled with tap water. Finally, $200 \mu \mathrm{l}$ of protein-sugar mixture was subjected to Gly-Pro assay to assess the extent of the glycation reaction.

\subsection{HMF analysis}

HMF amounts in casein-glucose and BSA-glucose model system solutions that were subjected to heat treatment at $60{ }^{\circ} \mathrm{C}$ were investigated spectrophotometrically according to the official method reported by AOAC (AOAC Official Methods of Analysis, 1999, Chap. 44).

\subsection{Food samples}

Food samples composed of honey $(n=4)$, pasteurized $(n=3)$, UHT $(n=2)$, sterilized $(n=2)$, concentrated $(n=1)$ and delactosed milk $(n=1)$, pear $(n=1)$ and orange juice $(n=1)$, were from local markets (Rome, Italy). For tomato samples including peeled tomato containing whole tomatoes $(n=2)$, tomato sauce; a liquid mixed tomatoes $(n=2)$ and tomato paste $(n=2)$, were purchased from both Italian and Moroccan markets.

Tomato samples were prepared as follow: $5 \mathrm{~g}$ of the product was weighed, then adjusted to a volume of $50 \mathrm{ml}$ with distilled water and mixed vigorously using a vortex agitator. The diluted mixture was centrifuged at $6000 \mathrm{rpm}$ for $15 \mathrm{~min}$. The supernatant was filtered through a $0.45 \mu \mathrm{m}$ filter using a vacuum pump. The final solution was used for the Gly-Pro assay.

Honey samples were prepared by dilution with distilled water $(1: 5 \mathrm{w} / \mathrm{v})$ prior to analysis.

Fruit juices chosen (pear and orange) were filtered through $0.45 \mu \mathrm{m}$ filter prior to use.

The milk samples were skimmed by centrifugation at $2500 \mathrm{rpm}$ for $15 \mathrm{~min}$ prior to analysis. The concentrated milk was diluted two times before being centrifuged.

It had to be noted that the delactosed milk is treated enzymatically during the fabrication process to transform the lactose into glucose and galactose as mentioned in the packaging.

\subsection{Analysis procedure with Gly-Pro kit}

The reactions involved in the Gly-Pro kit are illustrated in the following sequence: 


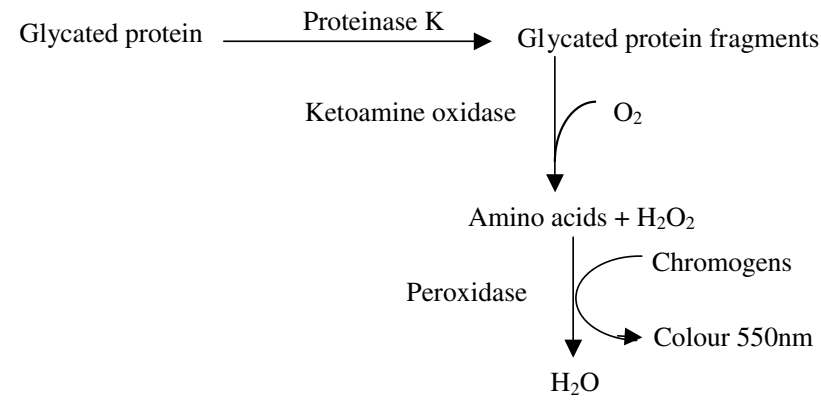

The assay of protein glycation using the Gly-Pro kit was carried out as follows: $250 \mu$ of the reagent 1 (ketoamine oxidase, peroxidase) was added to the cuvette containing an appropriate sample volume. This mixture was incubated at $37^{\circ} \mathrm{C}$ for $5 \mathrm{~min}$, and then $50 \mu \mathrm{l}$ of reagent 2 was added. The final volume in the cuvette was adjusted to $1 \mathrm{ml}$ with distilled water. The evolution of absorbance at $550 \mathrm{~nm}$ was followed until a steady state was reached (after 30-40 min). For milk products, the reagent 1 was added to $100 \mu 1$ of skimmed or diluted (concentrated milk) sample, let stand for 5 min then the second reagent was added and the reaction was allowed to proceed at room temperature for $40 \mathrm{~min}$ (end point). Finally, clarifying reagent $(600 \mu \mathrm{l})$ was added at the end of the enzymatic reactions. The assay mixture was incubated for 4 min at $37^{\circ} \mathrm{C}$ prior to the spectrophotometric measurement in quartz cuvette.

For honey and tomato paste samples, $25 \mu \mathrm{l}$ of the dilution was mixed with reagents of the Gly-Pro assay, however, $200 \mu \mathrm{l}$ of the sample or of the dilution was used in the case of the other food products.

\section{Results and discussion}

In the presence of glycated proteins, the enzyme proteinase $\mathrm{K}$ is able to produce glycated protein fragments, which then react with a second enzyme, the ketoamine oxidase, producing hydrogen peroxide. This latter acts as co-substrate of the Peroxidase enzyme, transforming a chromogen into a coloured product, whose absorbance is measured spectrophotometrically at $550 \mathrm{~nm}$. Thus, the increase in absorbance of a system subjected to the Gly-Pro kit procedure, can be related to the presence of glycated proteins.

A casein-glucose model system was selected to study the extent of casein glycation. It was incubated at $37^{\circ} \mathrm{C}$ from 2 to 5 days at various temperatures $\left(37\right.$ and $\left.60 ;{ }^{\circ} \mathrm{C}\right)$ and various holding times. Results, obtained with the Gly-Pro assay, showed an increase in absorbance related to the colour and proportional to the amount of glycated proteins.

The effect of heating on casein-glucose model was followed at two different temperatures, 37 and $60{ }^{\circ} \mathrm{C}$. (Fig. 1(a) and (b)) shows the absorbance profiles of casein-glucose solutions and the corresponding increase in the extent of glycation during heat treatment. While at $37^{\circ} \mathrm{C}$ (Fig. 1(a)) there was just a small increase in absorbance after 5 days, at $60^{\circ} \mathrm{C}$ the increase was quite high after $24 \mathrm{~h}$. The absorbance changed slightly (0.006) up to $1 \mathrm{~h}$ (Fig. 1(b)), then increased linearly during the time remaining. The mixture reached an absorbance equal to 0.473 after $24 \mathrm{~h}$ in water bath kept at $60^{\circ} \mathrm{C}$.

Glycation of casein with other sugars such as lactose, fructose, sucrose and galactose was also evaluated; however, no glycation reaction was observed when monitored by the Gly-Pro assay kit. Even after $24 \mathrm{~h}$ of reaction at $60^{\circ} \mathrm{C}$, no glycation products were seen with any of these other sugars, whereas an absorbance value of 0.475 was observed with glucose. These results suggest a high specificity of the Gly-Pro assay for glucoselinked glycation.

To confirm this hypothesis, another model system, constituted of BSA and glucose was investigated at the
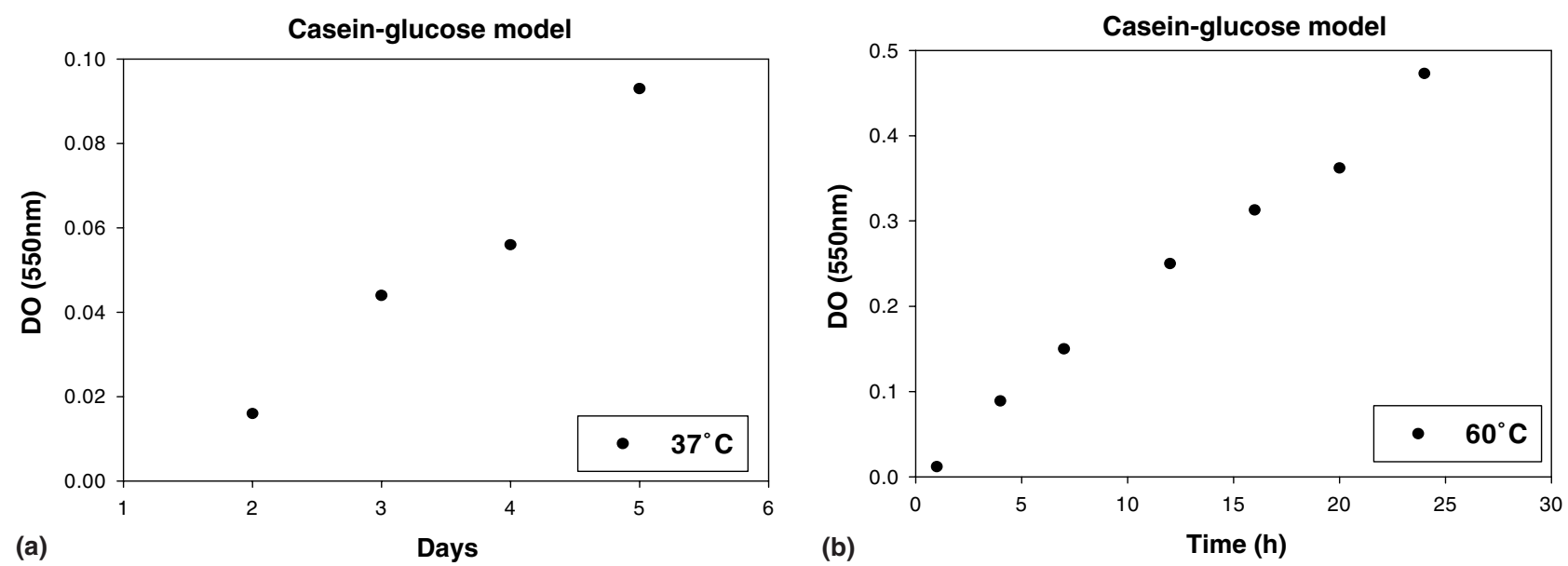

Fig. 1. Time course of the extent of glycation in casein-glucose mixtures heated at $37^{\circ} \mathrm{C}(\mathrm{a}) ; 60^{\circ} \mathrm{C}$ (b). 


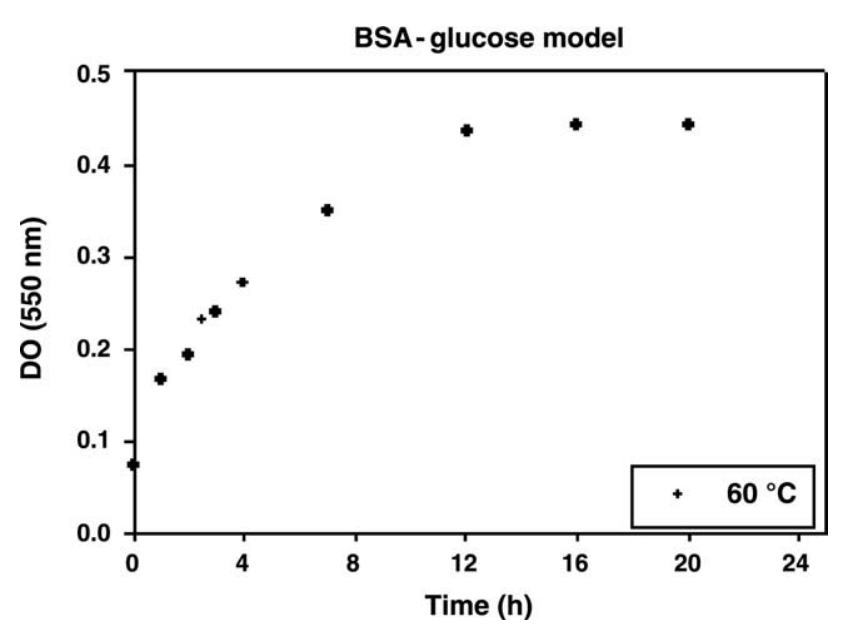

Fig. 2. Time course of glycation in heated mixture BSA-glucose at $60{ }^{\circ} \mathrm{C}$.

intermediate temperature of $60^{\circ} \mathrm{C}$ as for the caseinglucose model (Fig. 2). An increase in absorbance could be seen, but the behavior was markedly different from that of the casein-glucose mixture (Fig. 1(b) and Fig. 2). Glycation increased steadily to a plateau with a maximum of 0.441 between 12 and $16 \mathrm{~h}$. Then, there was a slow decline. It can be noted that this maximum value is similar to that reached in the casein-glucose system at $60{ }^{\circ} \mathrm{C}$, while, by contrast to the casein-glucose system, the BSA-glucose mixture showed an initial glycation even without heating (blank value was 0.072).

Comparing the two mixtures, the BSA-glucose system gave rise to a more rapid increase in absorbance than the casein-glucose model. It seems that initial glycation without heating is more favorable for BSAglucose mixture than casein-glucose mixture (Fig. 1(b) and Fig. 2)

HMF investigations have been realized using the BSA-glucose and casein-glucose models heated at $60{ }^{\circ} \mathrm{C}$ for $24 \mathrm{~h}$. The data obtained showed an increase in amounts of HMF in model solutions with increasing heating time. The HMF profile in function of incubation time at $60^{\circ} \mathrm{C}$ exhibits a linear equation for both BSA and casein based models. The equations obtained with BSA-glucose and casein-glucose are:

$y=44.15+1.58 x\left(R^{2}=0.997\right)$ and

$y=12.67+1.13 x\left(R^{2}=0.997\right)$,

respectively, where $y$ is the amount of $\operatorname{HMF}\left(\mathrm{mg}^{-1}\right)$ and $x$ is the heating time at $60^{\circ} \mathrm{C}(h)$.

As it shown, the BSA-glucose model showed a higher HMF concentration comparing to casein-glucose model. Further more, the initial concentration of HMF in unheated solution of BSA based model is higher than that of casein based model. These results are in accordance with those obtained with the Gly-Pro kit (Fig. 1(b) and Fig. 2) which showed that BSA is more reactive with sugar than casein and exhibits an initial glycation without heat treatment.

Different food products were also tested with Gly-Pro kit. The majority of these products are known to be subjected to heat treatment in their industrial processing where the Maillard reaction known to occur. The results obtained with the enzymatic kit are reported in Table 1 .

The table shows a variable extent of glycation (absorbance profile) for different tomato products analyzed. The data obtained showed that the absorbance was greater in concentrated tomato paste than sauce and peeled tomatoes. The tomato paste contained a higher amounts of proteins (22\%) and carbohydrates (4\%) comparing to peeled tomato and tomato sauce which contain $1.1 \%$ and $1.3 \%$ of proteins and, $3 \%$ and $4 \%$ of carbohydrates, respectively.

The data obtained from concentrated tomato pastes purchased from two different markets showed that the Italian product seems to contain a higher content of glycated protein relative to one bought in Morocco (Table 1).

The content of glycated protein in four honey samples was also determined. The average absorbance resulting was around 0.243 . The various honey samples showed a different extent of glycation. In general, the honey presents a high degree of glycation (high absorbance) certainly due to its higher content in sugar and their storage in ambient temperature.

Pear and orange juice samples were also analyzed and the results indicated that these products seem to not contain glycated protein. It is likely that juices initially contained a low protein concentration, reason for the absence of glycation in this type of products.

For pasteurized, UHT, and sterilized milk samples, we did not observe the presence of any glycated proteins as measured by the Gly-Pro kit. Only concentrated and

Table 1

Extent of glycation in different tomato products: peeled, sauce, and paste (Italian and Moroccan), honey samples, milk and juices products

\begin{tabular}{ll}
\hline Product & Absorbance $(550 \mathrm{~nm})$ \\
\hline Peeled tomato & 0.031 \\
Tomato sauce & 0.091 \\
Italian tomato paste & 0.278 \\
Moroccan tomato paste & 0.554 \\
Honey sample 1 & 0.290 \\
Honey sample 2 & 0.164 \\
Honey sample 3 & 0.384 \\
Honey sample 4 & 0.136 \\
Pasteurized milk & - \\
UHT milk & - \\
Sterilized milk & - \\
Concentrated milk & 0.060 \\
Delactosed milk & 0.050 \\
Pear juice & - \\
Orange juice & -
\end{tabular}


delactosed milks produced color with absorbance values of 0.060 and 0.050 , respectively. This can be explained by the composition of these products which contained a discrete amount of glucose and proteins.

\section{Conclusion}

The commercial kit designated Gly-Pro was used to follow glycation in experiments simulating the effect of storage and heating processes on food quality, especially on the reaction occurring between proteins and sugars. The results obtained showed that their formation depends on various factors such as the nature of protein and sugar, temperature and heating time. The data obtained from HMF analysis in protein-sugar models showed accordance with those obtained the applied enzymatic kit.

The Gly-Pro kit showed some limitations, since it was not able to detect glycated protein in free glucose foods (milk) and models. The ketoamine oxidase seems to be specific for the glycated fragments stemming from glucose-linked proteins.

Thus, the usefulness of the enzymatic limited by the specificity of ketoamine oxidase can be applied only for foods containing proteins and free glucose. The Gly-Pro assay is perhaps more interesting for measuring the evolution of glycated proteins in experimental surveys of storage and heat treatment effects on food quality, including those based on protein-sugar models.

Recent studies are focusing on the use of fructosyl amine oxidases (FAOs) and amadoriases combined with proteases as an enzymatic method for glycated protein measurements (Ogawa et al., 2002; Sode, Takahshi, Ohta, Tsugawa, \& Yamazaki, 2001).

\section{References}

Ames, J. M. (1992). The Maillard reaction. In B. J. F. Hudson (Ed.), Progress in Food Proteins and Biochemistry (pp. 99-153). Elsevier Applied Science.

Amine, A., Moscone, D., Bernardo, R. A., Marconi, E., \& Palleschi, G. (2000). A new enzymatic spectrophotometric assay for the determination of lactulose in milk. Analytica Chimica Acta, 406, 217-224.

AOAC. (1999). Official Methods of Analysis. (16th ed.) Chap. 44, method 980.23.

Buera, M. P., Chirife, J., Resnik, S. L., \& Wetzler, G. (1987). Nonenzymic browning in liquid model systems of high water activity: Kinetics of colour changes due to Maillard reaction between different single sugars. Journal of Food Science, 52, 1063-1067.

Chevalier, F., Chobert, J. M., Mollé, D., \& Haertlé, T. (2001a). Maillard glycation of $\beta$-lactoglobulin with several sugars: comparative study of the properties of the obtained polymers and the substituted sites. Lait, 81(5), 651-666.

Chevalier, F., Chobert, J. M., Popineau, Y., Nicolas, M. G., \& Haertlé, T. (2001b). Improvement of functional properties of $\beta$ lactoglobulin glycated through the Maillard reaction is related to the nature of the sugar. International Dairy Journal, 11, $145-152$.

EU Commission, (1992). Dairy Chemist's Group Doc. VI/5726/92. Rev. 2 Proposal of the Commission.

Finot, P. A., Deutch, R., \& Bujard, E. (1981). The extent of the Maillard reaction during the processing of milk. Progress in Food Nutrition Sciences, 5, 345-355.

Hidalgo, A., \& Pompei, C. (2000). Hydroxymethylfurfural and furosine reaction kinetics in tomato products. Journal of Agriculture and Food Chemistry, 48, 78-82.

Hidalgo, A., Pompei, C., \& Zambuto, R. (1998). Heat damage evaluation during tomato products processing. Journal of Agriculture and Food Chemistry, 46, 4387-4390.

Hidalgo, A., Rossi, M., \& Pompei, C. (1995). Furosine as freshness parameter of shell eggs. Journal of Agriculture and Food Chemistry, 43, 1673-1677.

Hodge, J. (1953). Chemistry of browning reactions in model systems. Journal of Agriculture and Food Chemistry, 1, 928-934.

IDF, (1998). Heat treated milk. Determination of lactulose content. Method using high-performance liquid chromatography. Standard 147B. Brussels: International Dairy Federation.

Maillard, L. C. (1912). Action des acides aminés sur les sucres: formation de melanöidines par voie méthodique. Compte Rendu de l'Académie des Sciences. (Paris), 154, 66-68.

Marconi, E., Messia, M. C., Amine, A., Moscone, D., Vernazza, F., Stocchi, F., et al. (2004). Heat-treated milk differentiation by a sensitive lactulose assay. Food Chemistry, 84, 447-450.

Morales, F. J., \& Van Boekel, M. A. J. S. (1997). A study on advanced Maillard reaction in heated casein/sugar solutions: Fluorescence accumulation. International Dairy Journal, 7, 675-683.

Morales, F. J., Romeo, C., \& Jiménez-Pérez, S. (2000). Characterization of industrial processed milk by analysis of heat-induced changes. International Journal of Food Science and Technology, 35, 193-200.

Morgan, F., Bouhallab, S., Mollé, D., Henry, G., Maubois, J-L., \& Léonil, J. (1998). Lactolation of $\beta$-lactoglobulin Monitored by Electrospray Ionization Mass Spectrometry. International Dairy Journal, 8, 95-98.

Mortier, L., Braekman, A., Cartuyvels, D., Renterghem, R. V., \& De Block, J. (2000). Intrinsic indicators for monitoring heat damage of consumption milk. Biotechnologie, Agronomie, Société et Environnement, 4, 221-225.

Moscone, D., Bernardo, R. A., Marconi, E., Amine, A., \& Palleschi, G. (1999). Rapid determination of lactulose in milk by microdialysis and biosensors. Analyst, 124, 325-329.

Ogawa, K., Stollner, D., Scheller, F., Warsinke, A., Ishimura, F., \& Tsugawa, W. (2002). Development of flow injection analysis (FIA) enzyme sensor for fructosyl amine monitoring. Analytical and Bioanalytical Chemistry, 373, 211-214.

Pagliarini, E., Vernile, M., \& Pei, C. (1990). Kinetic study on color changes in milk due to heat. Journal of Food Science, 55, 1766-1767.

Pallini, M., Compagnone, D., Di Stefano, S., Marini, S., Coletta, M., \& Palleschi, G. (2001). Immunodetection of lactosylated proteins as a useful tool to determine heat treatment in milk samples. Analyst, 126, 66-70.

Pellegrino, L., Van Boekel, M. A. J. S., Gruppen, H., Resmini, P., \& Pagani, M. A. (1999). Heat-induced aggregation and covalent linkages in $\beta$-casein model systems. International Dairy Journal, 9, 255-260.

Pizzano, R., Nicolai, M. A., Siciliano, R., \& Addeo, F. (1998). Specific detection of the amadori compounds in milk by using a polyclonal antibodies raised against a lactosylated peptide. Journal of Agriculture and Food Chemistry, 46, 5373-5379.

Rampilli, M., \& Andreini, R. (1992). Evaluation of colour components in sterilized milk. Italian Journal of Food Science, 4, 285-291.

Sode, K., Takahshi, Y., Ohta, S., Tsugawa, W., \& Yamazaki, T. (2001). A new concept for the construction of an artificial 
dehydrogenase for fructosylamine compounds and its application for an amperometric fructosylamine sensor. Analytica Chimica Acta, 435, 151-156.

Torrens, D.J., Shipley, D.P., Holdrige, M.B., Lane, S.R., Kalwass, H., (1998). Calibration of the enzyme glypro method for the specific enzymatic measurement of glycated protein. In: Proceedings of $A C B$ National Meeting, 63.

Villamiel, M., Corzo, N., Martinez-Castro, I., \& Olano, A. (1996). Chemical changes during microwave treatment of milk. Food Chemistry, 36, 385-388. 